\title{
Editorial
}

\section{All 'bout the Money? On the Division of Costs in the Context of EU Criminal Justice Cooperation and the Potential Impact on the Safeguarding of EU Defence Rights}

\author{
Jannemieke Ouwerkerk \\ Institute of Criminal Law and Criminology, Leiden University, \\ P.o. Box 9520, 2300 RA Leiden, The Netherlands \\ j.w.ouwerkerk@law.leidenuniv.nl
}

\section{$1 \quad$ Introduction}

Last year, in her Editorial for Volume 24, Issue 2-3 of this Journal, Estella Baker demanded attention for the financial impact of the European Union's criminal justice activities. She provided several examples to illustrate the (potential) financial costs involved in the application of EU legislation in the criminal justice sphere (such as mutual recognition instruments and directives on procedural rights). In order to enhance our understanding of the impact of the Eu's activities in criminal matters, Baker suggests an increased (academic) focus on the issue of financial costs such activities may have. ${ }^{1}$

Baker is right in that the seemingly trivial issue of money has so far been neglected in (EU) criminal law scholarship and I fully agree with her that the issue deserves more attention. ${ }^{2}$ This editorial answers Baker's call in that it

1 E. Baker, 'What Price Criminal Justice in the EU?, 24 European Journal of Crime, Criminal Law and Criminal Justice (2016) 95-105.

2 The relevance of this issue already emerged from my comparative legal research on criminal justice cooperation systems in federations (Switzerland and the USA) versus the European Union, see J. Ouwerkerk, Quid Pro Quo? A comparative law perspective on the mutual 
provides a critical reflection on the division of costs under the mutual recognition regime. While Baker indicates financial issues by category of EU activity, ${ }^{3}$ this piece takes it one step further. It attempts to demonstrate that the financial impact of EU legislation in one category-i.e. cross-border cooperation on the basis of mutual recognition-may have negative consequences for the implementation of $\mathrm{EU}$ legislation in another category-i.e. the safeguarding of procedural rights for suspects and accused persons.

2

\section{Strengthening Procedural Rights in Criminal Proceedings: The Eu Criminal Defence Rights Package}

In order to enhance the level of protection of procedural rights for suspects and accused persons, the European Union has been working, for more than a decade now, towards achieving common minimum standards in this field. This has not always been successful. To recall, the 2004 proposal for a Framework Decision on fair trial rights ${ }^{4}$ was discussed for years but eventually did not reach unanimous agreement in the Council. But then, shortly before the entry into force of the Lisbon Treaty, the Council adopted a Resolution on a step-by-step realisation of common minimum standards regarding criminal defence rights. ${ }^{5}$ This piecemeal approach turned out to be much more successful, maybe also because Article 82(2) TFEU requires qualified majority voting rather than unanimity.

So far, four directives have been adopted with regard to the following specific defence rights: the rights to interpretation and translation; the right to information (about rights, about the accusation and about the essential materials of the case); the right of access to a lawyer, and the right to communicate with third persons and consular authorities; the presumption of innocence (including inter alia the right not to incriminate oneself and the right to remain silent) and the right to be present at trial. ${ }^{6} \mathrm{~A}$ fifth directive provides

recognition of judicial decisions in criminal matters (Antwerp: Intersentia, 2011), in particular Chapters 4.4, 5.4 and 6.4.6.

3 Baker, supra note 1, in particular 97-100.

4 Proposal for a Council Framework Decision on certain procedural rights in criminal proceedings throughout the European Union $\operatorname{coM}(2004) 328$ final.

5 Resolution on a Roadmap for strengthening procedural rights of suspected or accused persons in criminal proceedings (2009) OJ C295/1.

6 Directive $2010 / 64 / \mathrm{EU}$ of 20 October 2010 on the right to interpretation and translation in criminal proceedings (2010) OJ L280/o1; Directive 2012/13/EU of 22 May 2012 on the right to information in criminal proceedings (2012) OJ L142/1; Directive 2013/48/EU of 22 October 2013 on the right of access to a lawyer in criminal proceedings and in European arrest warrant 
specific safeguards for suspected or accused children, such as the right to have a holder of parental responsibility informed and to have this person present during court hearings involving the child. ${ }^{7}$ Moreover, Council and Parliament have reached political agreement on the financial aspects of the right of access to a lawyer: In response to a proposed directive on the right to provisional legal aid, it was agreed that the instrument's scope should also include the right to ordinary legal aid. ${ }^{8}$

The strengthening of defence rights in the $\mathrm{EU}$ has been considered necessary to increase the level of trust amongst Member States in each other's criminal justice systems which in turn would facilitate the application of the mutual recognition principle in the context of criminal justice cooperation in the EU. ${ }^{9}$ This is in line with Article 82(2)(b) TFEU which provides the legal basis for minimum rules concerning procedural rights for suspects and accused persons "to the extent necessary to facilitate mutual recognition of judgments and judicial decisions and police and judicial cooperation in criminal matters having a cross-border dimension". So whereas common safeguards would unavoidably also apply in purely national criminal cases, the operation's main aim is to provide equivalent standards of defence rights in cross-border situations in which Member State cooperate (e.g., surrendering suspects).

\section{The Application of Eu Defence Rights in the Context of Cross-Border Cooperation}

In view of the operation's aim to promote mutual trust and to facilitate mutual recognition, it cannot surprise that most of the (proposed) defence rights have

proceedings, and on the right to have a third party informed upon deprivation of liberty and to communicate with third persons and with consular authorities while deprived of liberty (2013) OJ L294/1; Directive 2016/343/EU of 9 March 2016 on the strengthening of certain aspects of the presumption of innocence and of the right to be present at the trial in criminal proceedings (2016) OJ L 65/1.

7 Directive 2016/80o/EU of 11 May 2016 on procedural safeguards for children who are suspects or accused persons in criminal proceedings (2016) OJ L 132/1.

8 Proposal for a Directive on provisional aid for suspects and accused persons deprived of liberty and legal aid in European arrest warrant proceedings сом(2013) 824 (original proposal). On the political agreement, see this press release of the Council of the EU of 30 June 2016: http://www.consilium.europa.eu/en/press/press-releases/2016/o6/3o-legal-aid/ (last accessed 28 September 2016).

9 This follows from the preamble to the Resolution on a Roadmap for strengthening procedural rights of suspected or accused persons in criminal proceedings (supra footnote 5), in particular recitals $5^{-8}$. 
also been made applicable to proceedings for the execution of European arrest warrants. ${ }^{10}$ This goes for the rights to translation and interpretation, ${ }^{11}$ the right to be provided with a Letter of Rights, ${ }^{12}$ the right of access to a lawyer, ${ }^{13}$ some of the specific rights for children (e.g., the right to have the holder of parental responsibility informed, and the right to have this person present during court hearings involving the child), ${ }^{14}$ and the proposed right to legal aid. ${ }^{15}$

It is certainly not hard to imagine that persons whose surrender is sought actively exercise (one of) these defence rights, especially the rights to translation and interpretation, and the rights to legal assistance and legal aid. Because of the likelihood that a considerable number of sought persons will not understand the language of these surrender proceedings, it can be assumed that interpretation and translation services are frequently needed. Moreover, considering that persons whose surrender is sought are usually heard before being surrendered, and that a substantial percentage of them are taken into custody pending the court's decision on surrender, it is plausible that a large majority of sought persons is entitled to meet and consult a lawyer, to have him present during hearings - and this at the expense of the state if sufficient financial resources are lacking.

But also outside the context of surrender, one can think of situations of cross-border cooperation in which EU-level defence rights apply, for instance where pursuant to a European Investigation Order an individual who is under the suspicion of having committed a crime on the territory of Member State $\mathrm{X}$ would be questioned at a police station in Member State $\mathrm{Y}$ where he has been residing for a while. Such a situation would entitle the individual to consult a lawyer and to have him present while being heard. Moreover, if the individual is not able to understand the language during this hearing, he is also entitled to interpretation services. With regard to hearings by videoconferencing or other audiovisual transmission, the right to interpretation services has explicitly been recognised in Article 24(5)(d) of Directive 2014/41/EU regarding

\footnotetext{
10 Though the application to European arrest warrant proceedings was not mentioned in the 2009 Resolution, supra footnote 5 .

11 Articles 2(7) and 3(6) of Directive 2010/64/EU, supra footnote 6.

12 Article 5 of Directive 2012/13/EU, supra footnote 6.

13 Article 10 of Directive 2013/48/EU, supra footnote 6.

14 Article 17 of the Proposal for a Directive on procedural safeguards for children suspected or accused in criminal proceedings $\operatorname{COM}(2013) 822$.

15 Article 5 of the Proposal for a Directive on provisional aid for suspects and accused persons deprived of liberty and legal aid in European arrest warrant proceedings 824 .
} 
the European Investigation Order in criminal matters, ${ }^{16}$ which stipulates that "at the request of the issuing State or the person to be heard, the executing State shall ensure that the person to be heard is assisted by an interpreter, if necessary"-presumably, this provision must be read in conjunction with Directive $2010 / 64 / \mathrm{EU}$ on the right to interpretation and translation in criminal proceedings. ${ }^{17}$

Several other examples could be given, but for the aim of this paper the examples above suffice to demonstrate that EU-level defence rights are at issue in the context of cross-border cooperation between EU Member States, and also which of these defence rights are most likely to be exercised in this context.

\section{$4 \quad$ The Financial Impact of Safeguarding E U-Level Defence Rights under the Mutual Recognition Regime}

The effective exercise of some of the aforementioned Eu defence rights may cost a fair amount of money. This particularly applies for the apportion of translation and interpretation services as well as for the arrangement of legal assistance and legal aid. The considerable expense that the safeguarding of these rights may involve obviously raise concerns at the national level, for instance where these rights significantly exceed the level of protection that prior to the adoption of EU defence rights have already provided for in national law. ${ }^{18}$ But to spend money on the safeguarding of EU defence rights may feel even more problematic in the cross-border context in which EU-level defence rights apply as well. It follows from the previous paragraph that the most money-consuming rights-i.e., the rights to translation and interpretation, the right of access to a lawyer and the right to legal aid — will presumably most often be exercised in this particular context. As a consequence Member States may be held to spend quite a lot of money in relation to criminal cases that generally fall outside domestic interests. After all, the mutual recognition

\footnotetext{
16 O.J. 2014, L 130/1.

17 See supra, footnote 6. See also recital 15 of the preamble to Directive 2014/41/EU, supra footnote 16, which states that inter alia Directive 2010/64/EU must be taken into account when implementing Directive 2014/41/EU.

18 See, for instance, the position of the Dutch government (BNC-fiche) on the initial proposal $\operatorname{COM}(2010) 82$ as regards the right to interpretation and translation, in which it mentioned the "considerable increase of costs" ("aanzienlijke verhoging van de gerechtskosten") that written translations of essential documents would entail, see https://www.eumonitor .nl/935300o/1/j9vvik7mic3gyxp/vj846kl2tfwc (only available in Dutch, last accessed 5 October 2016).
} 
principle requires that in most cases expenses incurred in the course of the execution of foreign judicial decisions have to be borne by the executing Member States.

Pursuant to the principle of mutual recognition in criminal affairs, Member States are in principle obliged to attach legal consequences to judicial decisions that have been handed down in the legal order of any other Member States, in such a way as if these judicial decisions were handed down in the domestic legal order. The obligation to deal with foreign judicial decisions as if they were domestically taken includes the financial side of the matter. As a rule, Member States have to bear the costs that come with the recognition of foreign judicial decisions; this includes expenses made for the safeguarding of procedural rights in the course of recognition proceedings, either on the basis of the executing Member State's national law, or under the Eu defence rights package. That these costs are for the executing Member States follows, for instance, from Article 30(1) of Framework Decision 2002/584/JHA which determines that "expenses incurred in the territory of the executing Member State for the execution of a European arrest warrant shall be borne by that Member State". 19

The same principle applies under Directive $2014 / 41 / \mathrm{EU} .{ }^{20}$ In the previous section, this instrument has been identified as one of the instruments whose application is likely to give rise to the application of money-consuming EUlevel defence rights. Article 21(1) of Directive 2014/41/EU determines that " $\mathrm{u}]$ nless otherwise provided in this Directive, the executing State shall bear all costs undertaken on the territory of the executing State which are related to the execution of an EIO". Obviously the phrase "unless otherwise provided" implies that the Directive envisages exceptions to the rule that expenses made in the course of recognition proceedings are for the executing Member Statewhich is the case. However, these exceptions do not concern costs for the safeguarding of defence rights. ${ }^{21}$ To achieve that nevertheless the issuing Member State will foot (a considerable part of) the bill for the effectuation of defence

19 O.J. 2002, L 190/11.

20 This Directive is going to replace Framework Decision 2003/577/JHA of 22 July 2003 on the execution in the European Union of orders freezing property or evidence, 0.J. 2003, L 196/45 and Framework Decision 2008/978/JHA of 18 December 2008 on the European evidence warrant for the purpose of obtaining objects, documents and data for use in proceedings in criminal matters, O.J. 2008, L 350, 72.

21 Articles 22(10) and 23(3) stipulate that costs resulting from transferring a person held in custody for the purpose of carrying out an investigative measure shall be borne by the Member State to which this person is being transferred. Article $30(8)$ determines that the issuing Member State is held to bear the costs resulting from the transcription, decoding 
rights, the executing Member State needs to take recourse to the consultation opportunity, provided for in Article 21(2) of Directive 2014/41/EU: where prior to the execution of an incoming European Investigation Order the executing Member State would conclude that the actual execution would cost an exceptional high amount of money, it can consult the issuing Member State with a view to agreeing on an alternative division of costs. But any kind of entitlement to reimbursement has not been provided for, so the fact remains that the safeguarding of EU-level defence rights must in principle be borne by the executing Member State.

Rational as it may sound that in a criminal justice cooperation system based on the principle of mutual recognition the executing Member State is responsible for costs that arise on its territory, it is undeniable that such a rule is very likely to overcharge Member States, especially the less wealthier Member States and those Member States that receive an above-average number of European arrest warrants, evidence warrants, investigation warrants, or other mutual recognition requests which involve the safeguarding on their territory of money-consuming defence rights. In turn, in an attempt to keep the expenditure for foreign criminal cases under control, it is quite possible that Member States by some means or other will try to stint on the effective safeguarding of EU defence rights, such as by means of restricting access to these rights in practice, or through the narrowest interpretation of these rights. For example, one can imagine how a narrow interpretation of the terms 'essential documents' - which according to Article 3 of Directive 2010/64/EU qualify for being translated in a language the suspect understands - or a broad use of the exceptions to the rules of written translations and written summaries (Article 3(7) of Directive 2010/64/EU) positively impact on a Member State's budget, yet may hinder suspects to fully exercise their right of defence.

\section{$5 \quad$ For the Sake of Ensuring EU Defence Rights: Some Considerations on a Different Division of Costs in the Context of EU Criminal Justice Cooperation}

The foregoing argues that the effective safeguarding of procedural rights in EU criminal justice cooperation is under pressure, because the principle of mutual recognition requires Member State to pay for the execution of other Member States' requests. This is quite ironic: whereas the strengthening of procedural

and decrypting of communications intercepted with the technical assistance of another Member State. 
rights for suspects in criminal proceedings aims to facilitate mutual recognition, it is precisely the application of this mutual recognition principle as a result of which the more money-consuming procedural rights are liable to be set aside in the cross-border context.

Now one could reason that if Member States are cutting back on certain EUlevel defence rights in the context of judicial cooperation, they are simply not complying with what the various mutual recognition instruments stipulate, i.e. that incoming requests have to be recognised and enforced at their own expense. True as that may be, I consider it justified to question the fairness of this rule, not only in view of the tough economic times Member States have been going through over the past decade, but also considering the differences in prosperity levels between the Member States. Is it always fair to blame Member States for being reluctant to pay for other Member States' requests? Is it realistic and reasonable to demand Member States to spend money like water in relation to criminal proceedings that have been initiated by another Member State - and which possibly relate to an (alleged) criminal offence with which the executing Member State has not any connection at all? In my view, confirmative answers to these questions are not self-evident. However, it requires further research to know whether and to what extent the effective exercise of EU defence rights is actually being curtailed due to financial reasons, and also how costs accompanying the execution of mutual recognition orders, and particularly expenses in relation to the safeguarding of defence rights, could be distributed in a different manner. The following, very briefly, shares some first thoughts on how such an alternative division of costs might look like.

One way to reduce the financial burden of safeguarding EU-level defence rights in the course of mutual recognition proceedings would be to enable the executing Member State to get reimbursement for these expenses from the issuing Member State. For that aim, Member States need to agree on which of the EU defence rights qualify for reimbursement - it is conceivable that reimbursement will be restricted to those rights that are a particular strain on domestic resources, such as the rights to interpretation and translation as well as the rights to legal assistance and legal aid. Moreover, it could be arranged that the executing Member State only receives financial compensation for a fixed percentage of its expenses, or for expenses above a fixed amount - this to express that the safeguarding of $\mathrm{EU}$ defence rights and the functioning of the mutual recognition regime constitute common interests of the Member States.

The idea to enable direct reimbursement from the issuing Member State would fit well into the system of mutual recognition in which direct contact between competent authorities has simplified and enhanced cooperation practices between Member States. However, I am first to admit that the main 
challenge of such a system would be to deal with differing levels of prosperity, varying exchange rates in and outside the Eurozone, and, related to this, with diverging rates charged for translation and interpretation services, and for the provision of legal aid and the practical arrangements for the exercise of the right of access to a lawyer. For the possibility of being compensated for expenses made in relation to the cross-border safeguarding of EU-level defence rights is not supposed to restrain less wealthier Member States from issuing mutual recognition warrants out of fear for big bills from thriving executing Member States.

In view of that particular concern, it deserves consideration whetherinstead of a system of direct reimbursement from the issuing Member Statea fairer distribution of costs could be achieved by means of EU-level financial support. Within the framework of a purpose-built Eu Fund for EU-level defence rights, it will probably be easier to deal with the economic differences between Member States, and also with the differing numbers of cooperation requests that Member States issue and receive. One can think of a fund into which each of the Member States would deposit a sum of money, the proportion of which would be based on a variety of aspects, such as the size of population, the gross domestic product, the average number of mutual recognition requests that has been issued over the past 5 or 10 years, and possibly several other aspects.

However, after the example of the 'instrument for financial support for police cooperation', financial support at the EU-level could perhaps also be provided within the framework of the Internal Security Fund. The Internal Security Fund has been established as a comprehensive framework for Union financial support in relation to the implementation of the EU's Internal Security Strategy. The Fund currently comprises two instruments, one on financial support for police cooperation ${ }^{22}$ and another on financial support for external borders and visa. ${ }^{23}$ An important part of the budget allocated to the instrument on financial support for police cooperation is being implemented by so-called shared management: on the basis of the criteria of Article 6 of Regulation No. 513/2014, resources are allocated to Member States to support

\footnotetext{
22 Regulation (EU) No. 513/2014 of 16 April 2014 establishing, as part of the Internal Security Fund, the instrument for financial support for police cooperation, preventing and combating crime, and crisis management and repealing Council Decision 2007/125/J HA (2014) oJ L $150 / 93$.

23 Regulation (EU) No. 515/2014 of 16 April 2014 establishing, as part of the Internal Security Fund, the instrument for financial support for external borders and visa and repealing Decision No 574/2007/EC (2014) OJ L 150/143.
} 
national actions within the objectives of this Regulation, such as improving police cooperation and coordination between law enforcement authorities, joint investigation teams, the exchange of information, etc. (Articles 4 and 7 of Regulation No. 513/2014). The police financial support instrument might be of inspirational value for the development of a similar instrument regarding the safeguarding of $\mathrm{EU}$ defence rights in the framework of judicial cooperation.

Obviously, to arrange financial support through an EU Fund would still require Member States to spend money on the safeguarding of Eu-level defence rights; exercising defence rights does cost money and the money must come from somewhere. And true, also in the context of such an EU Fund, Member States might still be dissatisfied with the amount of money they would be required to deposit into such an EU Fund, especially where national contributions would differ considerably, or where the application of the allocation criteria would raise questions. Nevertheless, such a downside cannot outweigh the main benefit of an EU Fund, namely that it would offer a stronger protection of defence rights than under the current framework: Because disagreement amongst Member States has to be negotiated at the EU level, money issues would be far less likely to come to the detriment of the safeguarding of defence rights in individual cases.

\section{Conclusion}

This editorial has provided a critical reflection on the current division of costs in the context of judicial cooperation in criminal affairs. It was argued that this division of costs is very likely to have a negative impact on the safeguarding of EU defence rights in such situations of cross-border cooperation. Therefore, and also because of the likelihood that a different division of costs in the context of judicial cooperation in criminal affairs will facilitate a much more generous approach towards ensuring defence rights in cooperation proceedings, academics hopefully feel encouraged to pay more attention to the financial impact of EU legislation in these areas, and to the question of how an alternative cost allocation could contribute to the strengthening of EU defence rights. 